\title{
Особливості формування муконазального імунітету у спортсменів-легкоатлетів під впливом фізичного навантаження у тренувальному періоді
}

\section{УдК 612.017:796}

\author{
О. І. Осадча, О. О. Шматова, Г. М. Боярська
}

Національний університет фізичного виховання і спорту України, Київ, Україна

\begin{abstract}
Резюме. У роботі узагальнено результати обстеження 22 спортсменів (легкоатлети) 1819 років у передзмагальному та післязмагальному періодах. Мета. Вивчити особливості формування муконазального імунітету у спортсменів-легкоатлетів під впливом фізичного навантаження у тренувальному періоді. Методи. Усім спортсменам проводили дослідження вмісту в слині IgA, M, лактоферину та CR-реактивного протеїну як показників активності імунітету слизових оболонок у передзмагальному та післязмагальному періодах. Результати. Фактором розвитку захворювання практично завжди є зниження імунітету, в тому числі і місцевого, основним показником якого $є$ рівень IgA, M, лактоферину та CR-реактивного протеїну в слині. У спортсменів-легкоатлетів під впливом фізичного навантаження у тренувальному періоді визначено зменшення вмісту основних протиінфекційних ефекторних молекул слизових оболонок у післязмагальному періоді. Найбільш виражені зміни демонстрували показники вмісту slgA та IgM, що є потенційним фактором розвитку інфекційних захворювань як гострого, так і рецидивуючого характеру дихальних шляхів та слизових оболонок у цілому. Визначення статусу муконазального імунітету має істотне значення для діагностики і контролю лікування ряду захворювань кишечнику, верхніх дихальних шляхів, ротової порожнини, урогенітальної ділянки та ін. Це має значення для спостереження за станом спортсмена. Введення таких досліджень у практику спортивного лікаря дозволить розвинути персоніфіковану діагностику, лікарський моніторинг, оцінювання стану здоров'я конкретного спортсмена.

Ключові слова: фізичне навантаження, муконазальний імунітет, імуноглобуліни, лактоферин, CR-реактивний протеїн.
\end{abstract}

Features of formation of muconasal immunity in track and field athletes under the influence of physical load in the training period

\section{O. I. Osadcha, O. O. Shmatova, G. M. Boyarska}

National University of Physical Education and Sport of Ukraine, Kyiv, Ukraine

Abstract. The paper summarizes the results of a survey of 22 track and field athletes 1819 years in the pre-competitive and post-competitive period. Objective. To study the peculiarities of the formation of muconasal immunity in athletes under the influence of physical load during the training period. Methods. All athletes were examined for the content of IgA, M, lactoferrin and CR-reactive protein in saliva as indices of mucosal immune activity in the pre-competitive and post-competitive period. The factor in the development of the disease is almost always a decrease in immunity, including local, the main index of which is the level of IgA $M$, lactoferrin and CR-reactive protein in saliva. In athletes under the influence of physical loads in the training period, 
a decrease in the content of the main anti-infective effector molecules of the mucous membranes in the post-competitive period was determined. The most pronounced changes were shown by the indicators of slgA and IgM content, which is a potential factor in the development of infectious diseases of both acute and recurrent nature of the respiratory tract and mucous membranes in general. Determining the status of muconasal immunity is essential for the diagnosis and control of treatment of a number of diseases of the intestine, upper respiratory tract, oral cavity, urogenital region, etc. This is important for monitoring the condition of the athlete. Introduction of such researches in practice of the sports physician will allow to develop the personalized diagnostics, medical monitoring, an assessment of a state of health of the specific athlete.

Keywords: exercise muconasal immunity, immunoglobulins, lactoferrin, CR-reactive protein.

Постановка проблеми. Збільшення фрізичного навантаження у спортсменів все частіше супроводжується розладами імунної системи, вираженість яких залежить від інтенсивності і тривалості фрізичних вправ.

Місцевий імунітет відіграє важливу роль у захисті слизових оболонок респіраторного, кишкового й урогенітального трактів, кон'юнктиви очей, ротової порожнини. Захисні властивості слизових оболонок (запобігання проникненню антигенів до внутрішнього середовища організму) обумовлені комплексом фракторів (перистальтичні рухи, рух війок епітелію, виділення слизу, ферментів), а також виробленням імуноглобулінів і продукцією лізоциму, лактофрерину, інтерферону тощо [1].

Гуморальний імунітет слизових оболонок передбачає вироблення $\lg \mathrm{A}, \lg \mathrm{M}, \lg G$, а також секреторного $\lg A$ (slgA). Імуноглобуліни потрапляють у ротову порожнину з током крові, але їх можуть виробляти і плазмоцити. Потім імуноглобуліни проникають у місце імунного конфрлікту - підслизовий або слизовий шар. IgМ швидше з'являються на місці імунного конфрлікту. Вони менш ефективні, ніж lgG, але мають імуностимулюючу дію на місцеву лімфатичну систему.

До основних маркерів мукозального імунітету відносять slgA. Слина - основний матеріал для дослідження муконазального імунітету ротової порожнини і верхніх дихальних шляхів. Плазматичні клітини синтезують slgA, який у свою чергу відіграє першорядну роль у захисті слизових оболонок від бактерій, грибів і вірусів. Він перешкоджає взаємодії мікробів зі слизовою оболонкою, а також гальмує адгезію мікроорганізмів, їх токсинів і алергенів на поверхні епітелію слизових оболонок, цим самим запобігає їх проникненню у внутрішнє середовище організму $[1,2]$. Антиадгезивні властивості slgA лежать в основі його антибактеріальних, антивірусних ефектів.

Вироблення slgA - основна ефректорна функція імунної системи слизових оболонок, що забезпечує першу лінію захисту від патогенів. Ді- ючи спільно з іншими фракторами захисту, такими як бета-лізин, десрензини, комплемент, лізоцим та лактоферин, він забезпечує бактерицидність слини. Показано, що тривале та інтенсивне тренування сприяє зниженню концентрації slgA в слині. Зменшення секреції slgA в слині під час інтенсивних тренувань і хронічного стресу, ймовірно, пов'язано зі зміною активності гіпоталамо-гіпофрізарно-адреналової осі при інгібіторних впливах на синтез slgA і трансцитозу [3-5].

Мета дослідження - вивчити особливості фрормування муконазального імунітету у спортсменів-легкоатлетів під впливом фрізичного навантаження у тренувальному періоді.

Методи дослідження. Узагальнено результати обстеження 22 спортсменів (легкоатлети) 18-19 років у передзмагальний та післязмагальний періоди.

Збір слини проводили натщесерце в ранкові години шляхом спльовування в стерильну скляну колбу. Біомасу центрифругували, зберігали за температури $-30{ }^{\circ} \mathrm{C}$.

Присутність СРБ у ротовій рідині визначали реакцією преципітації, рівні $\lg A, \lg M$ i $\operatorname{sg} \mathrm{A}$ в слині - методом радіальної імунодифузії в гелі Манчіні $[6,7]$.

Кількісний вміст лактофрерину оцінювали методом твердофразного імуноферментного аналізу [8].

Результати та їх обговорення. Імуноглобуліни підтипів $\lg \mathrm{A}$ i $\lg \mathrm{M}$ зустрічаються у значних кількостях у тканинах слизових оболонок, наприклад у слизовій оболонці, що вистилає ротову порожнину і порожнину шлунково-кишкового тракту. Ці імуноглобуліни виконують важливу роль у захисті від патогенів, що проникають в організм з повітрям і їжею. Визначено тенденцію до зниження концентрації $\lg$ А в слині у спортсменів після фрізичного навантаження відносно референтних значень у другому терміні дослідження в 1,21 раза. При цьому встановлено, що продукція $\lg$ Ф більш чутлива до фрізичного навантаження. Концентрація даного імуноглобулі- 
ТАБЛИЦЯ 1 - Показники вмісту імуноглобулінів у слині спортсменів під впливом фізичного навантаження, $M \pm m, n=22$

\begin{tabular}{|l|c|c|c|}
\hline \multirow{2}{*}{$\begin{array}{c}\text { Досліджувані } \\
\text { показники, } \\
\text { МЕ/мл }\end{array}$} & $\begin{array}{c}|c| \\
\text { перший } \\
\text { термін }\end{array}$ & $\begin{array}{c}\text { другий } \\
\text { термін }\end{array}$ & $\begin{array}{c}\text { Референтні } \\
\text { значення }\end{array}$ \\
\hline $\lg \mathrm{A}$ & $1,44 \pm 0,19$ & $1,24 \pm 0,17$ & $1,51 \pm 0,05$ \\
\hline $\lg \mathrm{g}$ & $1,82 \pm 0,14$ & $1,16 \pm 0,14(\mathrm{p}<0,001)^{*}$ & $2,33 \pm 0,10$ \\
\hline slgA & $2,22 \pm 0,13$ & $\begin{array}{l}1,34 \pm 0,47(p<0,05)^{*} \\
(p<0,05)^{\star *}\end{array}$ & $2,98 \pm 0,35$ \\
\hline
\end{tabular}

* вірогідно порівняно з референтними значеннями;

** вірогідно порівняно з вихідними значеннями

ну в другому терміні досліджень була знижена відносно референтних значень в 2,01 раза ( $p<$ $<0,001)$.

На відміну від динаміки рівня імуноглобулінів $\lg \mathrm{A}$ та $\lg \mathrm{M}$, у профресійних спортсменів виявлено тенденцію до зниження рівня slgA в слині вже в першому терміні досліджень відносно референтних значень в 1,34 раза. При цьому після значного фрізичного навантаження було визначено значне зниження концентрації slgA відносно показників референтної групи в 2,22 раза ( $p<$ $<0,05)$, також відносно вихідних даних в 1,65 раза ( $<<0,05)$ (табл. 1).

Зміни вмісту $\lg$ в в слині відображали загальні зміни вироблення цього імуноглобуліну і викликали особливий інтерес у зв'язку з підвищеною частотою захворювань верхніх дихальних шляхів у спортсменів у період інтенсивних фрізичних тренувань [9].

Також відзначено, що значні фрізичні навантаження зумовлюють зниження продукції lgM у другому терміні досліджень відносно референтних значень в 2,01 раза ( $<<0,001)$. Антитіла класу $\lg$ М, які в нормі першими секретуються при гуморальній відповіді імунної системи у відповідь на первинний контакт організму з антигеном, і $€$ показниками гострого інфекційного процесу. lgM переважно циркулюють у кровотоці і становлять 5-10 \% усіх імуноглобулінів крові. Імуноглобуліни класу М синтезуються під час первинної імунної відповіді. Це найбільш ранні антитіла, які першими реагують 3 чужорідним агентом. Комплекс «lgM-антиген» активує класичний шлях системи комплементу. Антитіла $€$ показниками гострої фрази запалення. Зниження вмісту $\lg$ М у слизових під час значних фрізичних навантажень, на нашу думку, свідчить про дезадаптацію місцевого протиінфекційного імунітету у спортсменів.

Ми визначили вміст лактофрерину та CR-реактивного протеїну в слині у спортсменів під впливом фрізичного навантаження впродовж тренувального процесу.
У результаті проведених досліджень було встановлено, що значні фрізичні навантаження зумовлюють тенденцію до зниження концентрації лактофрерину відносно вихідних та ресрерентних значень в 1,19 та 1,33 раза відповідно (табл. 2).

Стабільне та постійне надходження слини, яка здійснює інтеграцію м'яких і твердих тканин у порожнині рота, забезпечує не тільки підтримання гомеостазу ротової порожнини й ефективне видалення ендо- та екзогенних мікроорганізмів і їх метаболітів, а й постійну присутність у порожнині рота різних захисних фракторів. Лактофрерин $\epsilon$ глікопротеїном із сімейства трансореринів і належить до ендогенних антимікробних пептидів, які відповідають за вроджений імунітет. Лактофрерин $є$ важливою складовою системи неспецифрічного антимікробного захисту слизових, володіє бактеріостатичними властивостями завдяки зв'язуванню грампозитивних та грамнегативних бактерій [9].

Ушкоджуючи зовнішню мембрану бактерій, лактофрерин дає можливість лізоциму впливати на пептидоглікан бактерій. Лактофрерин також має фрунгіцидні властивості та активний відносно багатьох вірусів. Зниження вмісту лактофрерину в слині може свідчити про наявність вторинної імунної недостатності неспецифрічної гуморальної ланки протимікробного захисту, яка фрормується під впливом значних фрізичних навантажень у спортсменів.

У процесі дослідження було встановлено тенденцію до підвищення вмісту CR-реактивного протеїну відносно вихідних показників в 1,10 раза та референтних значень в 1,04 раза.

CR-реактивний протеїн належить до так званих білків гострої фрази ушкодження тканин при некрозі, запаленні, травмі. С-реактивний білок, пов'язаний у комплекс із молекулами фоосратидилхоліну на поверхні багатьох бактерій, $є$ потужним опсоніном для моноцитів, стимулюючи перетравлення залучених організмів, бере участь у взаємодії Т- і В-лімфоцитів, активує класичний шлях комплементу [10, 11].

ТАБЛИЦЯ 2 - Показники вмісту лактоферину та CR-реактивного протеїну в слині спортсменів під впливом фізичного навантаження, $M \pm m, n=22$

\begin{tabular}{|c|c|c|c|}
\hline \multirow{2}{*}{$\begin{array}{c}\text { Досліджувані } \\
\text { показники, } \\
\text { МЕ/мл }\end{array}$} & \multicolumn{2}{|c|}{ Строки дослідження } & \multirow{2}{*}{$\begin{array}{c}\text { Рефрерентні } \\
\text { значення }\end{array}$} \\
\hline & $\begin{array}{c}\text { перший } \\
\text { термін }\end{array}$ & $\begin{array}{l}\text { другий } \\
\text { термін }\end{array}$ & \\
\hline Лактофрерин & $1,87 \pm 0,17$ & $1,65 \pm 0,14$ & $1,97 \pm 0,12$ \\
\hline $\begin{array}{l}\text { CR-реактив- } \\
\text { ний протеїн }\end{array}$ & $1,84 \pm 0,11$ & $2,01 \pm 0,19$ & $1,93 \pm 0,15$ \\
\hline
\end{tabular}


Підвищення рівня досліджених показників свідчить про високу вірогідність розвитку запальних реакцій у слизових оболонках та, як наслідок, зниження їх протиіноекційної резистентності.

Таким чином, імунологічна активність та бар'єрна фрункція слизової оболонки включають дві лінії захисту:

- механізм імунного виключення, що забезпечується мукоциліарним кліренсом;

- механізм імунної елімінації, або імунне усунення, що забезпечується імунною відповіддю слизового і підслизового шарів.

Специфрічні захисні механізми слизових оболонок забезпечують захист макроорганізму від впливу зовнішньої інфекції і внутрішньої агресії за рахунок активації імунокомпетентних і допоміжних клітин, а також вироблення імуноглобулінів різних класів (М, A), у тому числі секреторних (slgA).

Багато патологічних процесів, у тому числі інорекційних, тривають на тлі зниженого місцевого імунітету та призводять до вторинної імунної недостатності. При хронічній запальній реакції будь-якої етіології (інфекція, алергія та ін.) створюються умови для порушення фрункціонування муконазального імунітету, що підтверджено результатами даного дослідження.

$\lg$ А блокує неінфекційні алергени, перешкоджаючи розвитку токсичних і алергічних реакцій. Якщо в організмі виробляється достатня кількість $\lg \mathrm{A}$, він запобігає розвитку $\lg \mathrm{E}$-залежних алергічних реакцій. При цьому $\lg М €$ первинною ланкою гуморального протиінфекційного захисту.

Значення $\lg$ А для імунної відповіді проти вірусів і бактерій незаперечне, оскільки у деяких мікроорганізмів виявлені системи блокування $\lg$ А. Це спеціалізовані $\lg А$-протеази, фрерменти, здатні розщеплювати $\lg A 1$ людини. Ці фрерменти синтезують такі бактерії: Neisseria gonorrhoeae (збудник гонореї), Neisseria meningitides (викликає менінгіт), Streptococcus pneumoniae, Streptococcus sanguis, Haemophilus influenzae, Bacteroides.

Зменшення вмісту $\lg$ А в слині обстежених спортсменів свідчить про зниження бар'єрної фрункції слизової оболонки верхніх дихальних шляхів. Як наслідок - підвищення ризику захворюваності інфрекційної та вірусної природи.

У той час показники рівня slgA свідчать про розвиток адаптивної імунної відповіді, спрямованої на формування механізмів адаптації до стресу та зміни зовнішніх умов. Секреція slgA дозволяє вважати даний клас імуноглобулінів важливим у захисті слизових покривів відкритих біотопів. Рівень slgA значною мірою відображає активність секреторних механізмів системи імунітету слизових оболонок. SlgA $\epsilon$ біологічним маркером, який виявляє зміни системи регуляції організму у відповідь на агресивні фрактори зовнішнього середовища (екологічне неблагополуччя, зростання стресових впливів, неповноцінне харчування, інфекція, масове безконтрольне застосування антибіотиків, хіміотерапевтичних препаратів і т.д.). Величина змін рівнів $\operatorname{sg} A$ в секретах залежить від тривалості несприятливих впливів на організм, генетичних особливостей і резервів. SlgA - маркер адаптації організму людини до зовнішніх впливів [12].

Зниження вмісту $\lg$ у у слизових оболонках під час значних фрізичних навантажень, на нашу думку, свідчить про дезадаптацію місцевого протиінфекційного імунітету у спортсменів [13, 14].

Виявлене нами зменшення активності лактоферину в слині може призводити до зниження фагоцитозу і літичної активності комплексу slgA із С3-компонентом комплементу щодо грамнегативних бактерій, що зменшує резистентність слизових оболонок до проникнення патогенів різної природи. Такі тенденції сприяють підвищенню захворюваності спортсменів на гострі та рецидивуючі інфекції дихальних шляхів і слизових оболонок у цілому.

Таким чином, у спортсменів-легкоатлетів під впливом фрізичного навантаження у тренувальному періоді визначено зменшення вмісту основних протиінфекційних ефекторних молекул слизових оболонок, що $є$ потенційним фактором розвитку інфекційних захворювань як гострого, так і рецидивуючого характеру.

Фактором розвитку захворювання практично завжди $є$ зниження імунітету, в тому числі і місцевого, основним показником якого є рівень $\lg \mathrm{A}, \mathrm{M}$, лактофрерину та CR-реактивного протеїну в слині. Визначення статусу муконазального імунітету має істотне значення для діагностики і контролю лікування ряду захворювань кишечнику, верхніх дихальних шляхів, ротової порожнини, урогенітальної ділянки та ін. При цьому слід врахувати, що стан здоров'я окремого індивіда складається 3 його генетичних особливостей і фенотипічних проявів організму під впливом фракторів зовнішнього середовища. Тому особливу цінність мають не абсолютні значення показників місцевого імунітету, а їх зміни в часі. Це має значення для спостереження за станом здоров'я спортсмена. Введення таких досліджень у практику спортивного лікаря дозволить розвинути персоніфіковану діагностику, лікарський моніторинг, оцінювання стану здоров'я конкретного спортсмена $[13,14]$. 
Спортивна медицина, фізична терапія та ерготерапія №2, 2021

\section{Література}

1. Цывкина АА, Лусс ЛВ, Царев СВ и др. Мукозальный иммунитет и его особенности при хроническом полипозном риносинусите [Mukozal'nyy immunitet i yego osobennosti pri khronicheskom polipoznom rinosinusite]. Физиология и патология иммунной системы. 2010,14(8):12-5.

2. Аршинова СС, Будихина АС, Симонова АВ и др. Оценка мукозального иммунитета [Otsenka mukozal'nogo immuniteta]. Российский аллергологический журнал. 2007;3.(1):329-30.

3. Libicz S, Mercier B, Bigou N. et al. Salivary IgA response of triathletes participating in the French Iron Tour. Int. J. Sports Med. 2006;27,(5):389-94.

4. Хаитов РМ. Физиология иммунной системы [Fiziologiya immunnoy sistemy]. Москва: ВИНИТИ РАН, 2005. 428 с.

5. Валышев АВ. Роль лактоферрина в противоинсрекционной защите [Rol' laktoferrina v protivoinfektsionnoy zashchite]. Успехи современной биологии. 2011;2:135-44.

6. Долгов ВВ, Меньшикова ВВ. Клиническая лабораторная диагностика [Klinicheskaya laboratornaya diagnostika]. Национальное руководство в 2 т. Том 1. М.: ГЭОТАР-Медиа, 2012. 928 с.

7. Turin CG, Zea-Vera A, Rueda MS, Mercado E, Carcamo CP, Zegarra J. et al. Lactoferrin concentration in breast milk of mothers of low-birthweight newborns. J Perinatol. 2017;37(5):507-12.

8. Воробьев АА, Быков АС, Караулов АВ. Иммунология и аллергология [Immunologiya i allergologiya]. Москва: Практическая медицина, 2006.

9. Шартанова НВ. Особенности мукозального иммунитета у спортсменов высших достижений [Osobennosti mukozal'nogo immuniteta u

osadchay1965@gmail.com

R_Shmatov@ukr.net

bojarska@rambler.ru sportsmenov vysshikh dostizheniy]. Эффрективная фрармакотерапия, аллергология и иммунология. 2015,2-3(48):56-690.

10. Кишкун АА. Руководство по лабораторным методам диагностики [Rukovodstvo po laboratornym metodam díagnostiki]. Москва, 2010. 234 c.

11. Михайлов ИБ. Настольная книга врача по клинической фармакологии: Руководство для врачей [Nastol'naya kniga vracha po klinicheskoy farmakologii: Rukovodstvo dlya vrachey]. СПб., 2010.157 c.

12. Виха ГВ, Папазов ИП, Воложин АИ и др. Секреторный иммуноглобулин A (slgA) в доказательной лабораторной диагностике [Sekretornyy immunoglobulin A (slgA) v dokazatel'noy laboratornoy diagnostike]. Сб. Нетрадиционные природные ресурсы, инновационные технологии и продукты. 2005; 13:89-102.

13. Футорний СМ, Осадча ОІ, Маслова ОВ, Шматова ОО. Особливості розвитку імунного дистресу у спортсменів у динаміці тренувального процесу [Osoblyvosti rozvytku imunnoho dystresu u sport-smeniv u dynamitsi trenuval'noho protsesu]. Теорія і методика фізичного виховання і спорту. 2016;4:61-5

14. Осадча ОІ, Футорний СМ, Імас ЄВ, Шматова ОО, Маслова ОВ. Особливості імунологічної адаптації під впливом значних фізичних навантажень [Osoblyvosti imunolohichnoyi adaptatsiyi pid vplyvom znachnykh fizychnykh navantazhen']. Науковий часопис Національного педуніверситету ім. МП. Драгоманова. Серія № 15 «Науково-педагогічні проблеми фізичної культури. Фізична культура і спорт». 2018;10(104)18:93-8. 